\title{
Raman Spectroscopic Analysis of Signaling Molecules-Dopamine Receptors Interactions in Living Cells
}

\author{
Achut P. Silwal and H. Peter $\mathrm{Lu}^{*}{ }^{\circ}$ \\ Department of Chemistry and Center for Photochemical Sciences, Bowling Green State University, Bowling Green, Ohio 43403, \\ United States
}

\section{Supporting Information}

ABSTRACT: The selective interaction of signaling compounds including neurotransmitters and drugs with the dopamine receptors (DARs) is extremely important for the treatment of neurodegenerative diseases. Here, we report a method to probe the selective interactions of signaling compounds with D1 and D2 DARs in living cells using the combined approach of theoretical calculation and surface-enhanced Raman spectroscopy (SERS). When signaling compounds such as DA, amphetamine, methamphetamine, and methylenedioxypyrovalerone interact with D1 dopamine receptors (DRD1), the intracellular cyclic adenosine monophosphate (cAMP) level is increased. However, the intracellular level of cAMP is decreased when D2 dopamine receptors (DRD2) interact with the abovementioned signaling

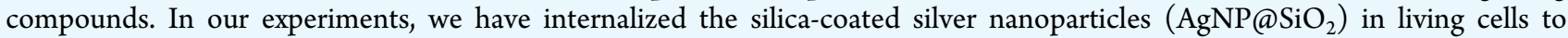

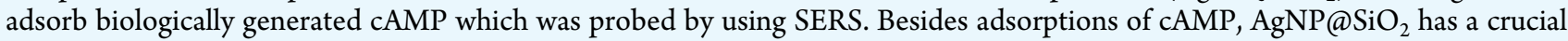
role for the enhancement of Raman cross section of the samples. We observed the characteristic SERS peaks of cAMP when DRD1-overexpressed cells interact with the signaling compounds; these peaks were not observed for other cells including DRD2-overexpressed and DRD1-DRD2-coexpressed cells. Our experimental approach is successful to probe the intracellular cAMP and characterize the selectivity of signaling compounds to different types of DARs. Furthermore, our experimental approach is highly capable for in vivo studies because it can probe intracellular cAMP using a low input power of incident laser without significant cell damage. Our experimental results and density functional theory calculations showed that 780 and 1503 $\mathrm{cm}^{-1}$ are signature Raman peaks of cAMP. The SERS peak at $780 \mathrm{~cm}^{-1}$ is associated with $\mathrm{C}-\mathrm{O}, \mathrm{C}-\mathrm{C}$, and $\mathrm{C}-\mathrm{N}$ stretching and symmetric and asymmetric bending of two $\mathrm{O}-\mathrm{H}$ bonds of cAMP, whereas the SERS peak at $1503 \mathrm{~cm}^{-1}$ is contributed by the $\mathrm{O}_{9}-\mathrm{H}_{3}$ bending mode.

\section{INTRODUCTION}

The G protein-coupled receptor (GPCR) is the largest superfamily of membrane proteins, which comprises more than 800 protein-coding human genes. ${ }^{1}$ It is a heptahelical transmembrane protein, which controls and regulates many activities including vision, test, smell, thinking, and behaviors. It is activated by a huge range of stimuli such as hormones, pheromones, light, peptides, odorants, and neurotransmitters. ${ }^{2}$ Dopamine receptors (DARs) are a type of GPCRs, which are primarily activated by dopamine (DA) and produce dopaminergic signals in mammalian brains (Figure 1). Mainly, five types of human DARs are reported in the literature: D1, D2, D3, D4, and D5 DARs, which are classified into two classes: (1) the D1-like DARs comprise D1 and D5 DARs and (2) the D2-like DARs comprise D2, D3, and D4 DARs. This classification is based on the sequence homology and functions of DARs. Although a high degree of similarity is found between DARs of similar classes, each type of DAR is encoded with different genes. For example, the D1 DAR is encoded by DRD1 genes and D5 DAR is encoded by DRD5 genes. ${ }^{3-6}$ Many DARs are expressed heterogeneously in cells, and it is very difficult to target selectively to a specific type of DARs. Nevertheless, in vivo characterization of DARs and their selective interaction with signaling compounds have great pharmaceutical importance to understand the synaptic and neural circuit action produced by DA and other signaling compounds.

DARs have several roles in the central nervous system of a human body, such as cognition, motivation, memory, motor control, and modulation of neuroendocrine activities. The termination of the $G$ protein signaling and the initiation of the $G$ protein-independent signaling are also regulated by DARs. $^{7-9}$ The D1-like DARs are also known to interact with $\mathrm{N}$-methyl-D-aspartate (NMDA) and gamma-aminobutyric acid (GABA) receptors via their intercellular loops and Ctermini. ${ }^{10-12}$ D1-like DARs couple with the Gs/olf subunit of the heterotrimeric $\mathrm{G}$ protein, which stimulates the synthesis of cyclic adenosine monophosphate $\left(3^{\prime}, 5^{\prime}\right.$-cyclic adenosine

Received: July 20, 2018

Accepted: October 16, 2018

Published: November 5, 2018 

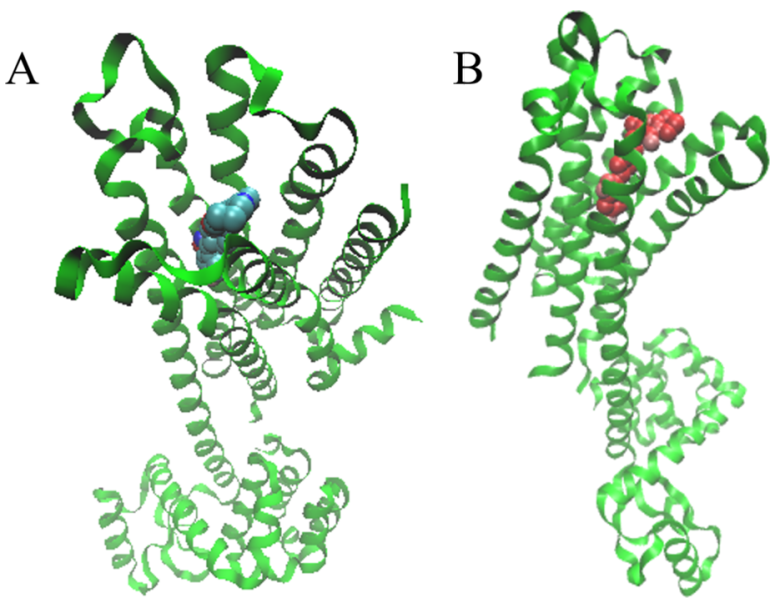

Figure 1. (A) Homology model of D1 DARs and (B) structure of D2 DAR bound to the atypical antipsychotic drug risperidone (PDB ID 6CM4).

monophosphate, cAMP) in cells, ${ }^{13}$ whereas D2-like receptors couple with the $\mathrm{Gi} / \mathrm{o} / \mathrm{z}$ subunit of the $\mathrm{G}$ protein and inhibit the synthesis of cAMP. ${ }^{14}$ cAMP is an important secondary messenger, which has several roles including the regulation of downstream proteins, ${ }^{15}$ ion channels, ${ }^{16-19}$ and transcription factors. $^{20-22}$ cAMP is synthesized from adenosine triphosphate (ATP) by the action of adenylate cyclase. cAMP could be converted back into ATP by the catalytic action of phosphodiesterase. ${ }^{23-26}$ cAMP has regulating roles in several biochemical processes such as metabolism of glycogens and lipids. ${ }^{27}$ Besides, it also activates the calcium channel for the release of growth hormones. ${ }^{28-30}$ Because a change of the cAMP concentration in a live cell is connected to the interaction of DARs, we have utilized cAMP as a key compound in this study.

The biochemical functions of DARs only occur after their interactions with signaling molecules or any other stimuli. Therefore, the probing of interactions between signaling molecules such as DA, amphetamine (AMP), methamphetamine (MAMP), and methylenedioxypyrovalerone (MDPV) and DARs has high medical impacts. Both D1 and D2 DARs have a crucial role as targets for antipsychotic drugs. Most of the clinically approved drugs still show poor selectivity between different types of DARs. Highly specific drugs are extremely important to cure the neuropsychiatric and endocrine disorders because the poor selectivity of a drug has severe side effects. Wide numbers of experimental and computational approaches including ligand binding assay,,$^{31-36}$ positron emission tomography (PET), ${ }^{37}$ single photon emission computed tomography (SPECT), ${ }^{38}$ and highthroughput screening ${ }^{39}$ are used for the pharmacological and chemical characterizations of signaling molecules (drugs) and their selectivity to a specific DAR. ${ }^{40-60}$ Fluorescence microscopy is one of the important techniques for the imaging of biological samples, but this technique suffers from some limitations, including the photobleaching effect, phototoxicity in living cells due to shorter wavelength of light, and cytotoxicity due to byproduct formation in situ photochemical reactions. ${ }^{61-66}$ Some literature has also reported the changes in the biological property of the sample after fluorescence labeling. ${ }^{67,68}$ Similarly, the radio ligand binding assay ${ }^{69}$ produces toxic radioactive wastes which are extremely harmful to in vivo studies. Although the above-mentioned techniques are useful to screen the binding specificity of signaling molecules such as drugs and neurotransmitters, they suffer from some serious limitations. For example, analytical results obtained from the above-mentioned techniques are based on the observation of a ligand-receptor complex rather than a product formation scheme. Therefore, the results from the above-mentioned experimental techniques have a complexity to explain precisely about the effective interactions between signaling molecules and proteins. Therefore, it is highly desirable and necessary to use a product-based technique to probe the ligand-protein interactions. Here, we report our application of surface-enhanced Raman spectroscopy (SERS) techniques to study the interaction between DARs and signaling molecules such as DA, AMP, MAMP, and MDPV in live cells.

Raman spectroscopy, one of the sensitive and selective chemical identification and analytical approach, was introduced to study the biological sample from the analysis of bacteriorhodopsin, which was later extended to study the salmon sperm and other living cells. ${ }^{70-72}$ Different forms of Raman spectroscopy are established as a powerful analytical approach for the label-free characterization of diverse biological molecules including heme protein, membrane protein, protein coenzymes, porphyrins, and highly organized systems such as photosynthetic reaction centers and membrane preparation bacteria. ${ }^{73-80}$ The enhancement of Raman cross section in the SERS technique is achieved by exploiting the electromagnetic and chemical enhancement mechanisms using a metallic substrate, especially a rough surface, or nanoparticles (NPs) of gold or silver. ${ }^{81}$ The metal NP used in Raman experiments also has another advantage such as the quenching of the fluorescence background. ${ }^{82-84}$ The combined approach of SERS and other techniques including fluorescence microscopy and electrophysiology is widely used to investigate the huge range of biological samples. ${ }^{85-94}$ Although the SERS technique has a wide range of useful applications, there are some limitations. For example, the SERS substrate denatures proteins during the experiment, which is due to the direct interaction of the $\mathrm{Ag}^{+}$ion or metal with the sulfhydryl group of the protein. ${ }^{95,96}$ The direct interaction of the metal NP with the cells also causes cytotoxic problems. ${ }^{97,98}$ The prevention of direct interactions between the metallic surface and biological molecules is highly desirable and recommended to protect biological samples during the SERS experiment, which was achieved in our experiment by generating an ultrathin layer $(4-6 \mathrm{~nm})$ of silica over silver NPs (AgNPs). ${ }^{77,80,99,100}$ It is known that these NPs are capable of preventing the denaturation of proteins and cytotoxicity in cells without reducing the electromagnetic field enhancement. ${ }^{98,99}$

In this study, the SERS spectra from DRD1, DRD2, and DRD1-DRD2-co-overexpressed cells and baseline cells in the absence and presence of signaling compounds including DA, AMP, MAMP, and MDPV were analyzed to test the effective and selective interaction of these compounds with DARs. When signaling molecules such as DA, AMP, MAMP, and MDPV were added to DRD1-expressed cells, the characteristic SERS peaks of cAMP were observed, which helped us to confirm the effective interaction between DRD1 and these signaling compounds. However, the interaction between signaling compounds and DRD2 was comparatively difficult to probe because this interaction is related to depletion of the cAMP level in cells, which does not give off any new SERS peaks. Therefore, experiments in DRD1-DRD2-co-overex- 
pressed cells were required to test the selective interaction of a signaling compound with DRD2 receptors. The DRD1DRD2-coexpressed cells did not show the SERS peaks of cAMP in the presence of signaling compounds, which indicated two possibilities: (1) signaling compounds were either selective to DRD2 receptors only or (2) they were equally selective to both DRD1 and DRD2 receptors and the resultant effect to produce cAMP was canceled. The first possibility was ruled out because all four signaling compounds had interacted with the DRD1 receptor and induced the cAMP level in the cells. The analysis of our results showed that all four signaling compounds are equally selective to both DRD1 and DRD2 receptors. Our experimental results and density functional theory (DFT) calculations show that 780 and 1503 $\mathrm{cm}^{-1}$ are signature Raman peaks of intracellular cAMP. The visualization of the calculated molecular vibration shows that the SERS peak at $780 \mathrm{~cm}^{-1}$ is associated with $\mathrm{C}-\mathrm{O}, \mathrm{C}-\mathrm{C}$, and $\mathrm{C}-\mathrm{N}$ stretching and symmetric and asymmetric bending of two $\mathrm{O}-\mathrm{H}$ bonds of cAMP, whereas the SERS peak at 1503 $\mathrm{cm}^{-1}$ is contributed by its $\mathrm{O}_{9}-\mathrm{H}_{3}$ bending mode.

\section{MATERIALS AND EXPERIMENTAL SECTION}

2.1. Overexpression of DRD1 and DRD2 in Cells. HEK293 and HT22 cells were cultured in $75 \mathrm{~cm}^{2}$ flasks in a complete medium which was obtained by mixing Dulbecco's modified Eagle's medium (Sigma-Aldrich D5796) with 10\% fetal bovine serum (Sigma-Aldrich, F2442) and 1\% penicillinstreptomycin (ATCC, 30-2300) at $37{ }^{\circ} \mathrm{C}$ in $5 \% \mathrm{CO}_{2}$ atmosphere. ${ }^{101}$ When the cells reached $\sim 75 \%$ confluence, they were ready for the subculture. For the SERS measurement, the cells were subcultured on a $25 \mathrm{~mm}$ circular cover glass in a $35 \mathrm{~mm}$ Petri dish. When the cells reached 50\% confluence on the cover glass, they were transfected with the plasmid for the overexpression of DARs. We used tango-DRD1 (66268) and GFP-DRD2 (24099)-encoded plasmid DNA, respectively, for the expression of D1 and D2 DARs. We purchased these plasmids from Addgene as the bacteria in the agar stab. The plasmids were amplified according to the standard protocol. Briefly, the bacteria from the agar stab were separately streaked on the surface of an LB agar plate using a sterile wire loop. Each LB plate was kept inside a small incubator for $16 \mathrm{~h}$ at $37^{\circ} \mathrm{C}$. Bacteria were grown on the $\mathrm{LB}$ plate as colonies with a copy of plasmids. Then, a single bacterial colony was separated and transferred into a falcon round-bottom tube containing $6 \mathrm{~mL}$ of LB solution with 100 $\mu \mathrm{g} / \mathrm{mL}$ ampicillin. The falcon tube was placed in a rotating incubator for $24 \mathrm{~h}$ at $37{ }^{\circ} \mathrm{C}$ to grow bacteria. Then, the bacteria were extracted from the $\mathrm{LB}$ solution in a $2 \mathrm{~mL}$ centrifuge tube in the form of a solid residue by the centrifuge process. This residue was dissolved with the resuspension reagent (Thermo Scientific, GeneJET Plasmid Miniprep kit, cat. no. K0502) and added with the lysis and neutralization solution to separate cell membranes and plasmids from the bacteria. The resulting solution was centrifuged for $15 \mathrm{~min}$ at $1200 \mathrm{rpm}$, and the supernatant solution was filtered through a miniprep or gene jet spin column to remove the filtrate. The content adsorbed on the filter was washed with the wash buffer to remove any adsorbed alcohol. Finally, the filter was washed twice with $25 \mu \mathrm{L}$ of elution buffer to collect a total $50 \mu \mathrm{L}$ of 1 $\mathrm{mg} / \mathrm{mL}$ plasmid DNA solution. For efficient gene transfer by transfection, we followed a protocol of lipid-mediated transfection with Lipofectamine LTX and PLUS reagent (Invitrogen, 11668-019). The day before transfection, the antibiotic-containing growth medium was replaced with the growth medium without antibiotics (penicillin-streptomycin). The preparation of the DNA reagent that was required to be added into the cell samples is explained briefly as follows: 50 $\mu \mathrm{L}$ of Opti-MEM-reduced serum medium was taken in a $2 \mathrm{~mL}$ centrifuge tube and added to $4 \mu \mathrm{L}$ of Lipofectamine LTX solution; however, the amount of Lipofectamine LTX could be varied. The mixture was vortexed and labeled as (1). Then, 250 $\mu \mathrm{L}$ of Opti-MEM medium and $5 \mu \mathrm{L}$ of plasmid DNA were taken in a $2 \mathrm{~mL}$ centrifuge tube and added to $5 \mu \mathrm{L}$ of PLUS reagent, which was labeled as (2). Then, $50 \mu \mathrm{L}$ of solution (2) was mixed with solution (1), and this mixed solution was kept at room temperature for $5 \mathrm{~min}$ for incubation. After incubation, $50 \mu \mathrm{L}$ of this mixed solution was added into the cells. The transfection of cells with DRD1 and DRD2 was confirmed by the observation of tango and green fluorescence, respectively.

2.2. Synthesis of Silica-Coated AgNPs. AgNPs were synthesized by a standard sodium citrate reduction method, ${ }^{102}$ followed by the addition of active sodium silicate to generate ultrathin silica shells over AgNPs. ${ }^{103}$ Silver nitrate $\left(\mathrm{AgNO}_{3}\right)$, sodium citrate, and sodium silicate required for the synthesis of NPs were purchased from Sigma-Aldrich and used without further purification. The AgNPs and $\mathrm{AgNP} @ \mathrm{SiO}_{2}$ were characterized by transmission electron microscopy and a Varian UV-vis spectrophotometer (EL07013173), respectively. The size of AgNP@SiO 2 particles was found to be $80 \pm$ $10 \mathrm{~nm}$ with the $\mathrm{SiO}_{2}$ shell thickness $5 \pm 1 \mathrm{~nm}$ (Figure S1). The $\mathrm{UV}$-vis measurement shows the maxima $\left(\lambda_{\max }\right)$ of the plasmon resonance band position of the AgNP colloid at $420 \mathrm{~nm}$, which was shifted to $407 \mathrm{~nm}$ for AgNP@SiO ${ }_{2}{ }^{77}$

2.3. Surface-Enhanced Raman Measurements. SERS spectra were collected using a home-modified confocal Raman microscope ${ }^{104}$ (Figure S2) using a $488 \mathrm{~nm}$ continuous-wave (CW) argon-ion laser of approximately $10 \pm 5 \mu \mathrm{W}$ power. We used $30 \mathrm{~s}$ integration time for the recording of a SERS spectrum. Mercury lamp and cyclohexane were used to calibrate the setup before Raman measurements with a spectral resolution of $2 \mathrm{~cm}^{-1}$. For the analysis of conventional SERS spectrum, we selected the range of $700-1700 \mathrm{~cm}^{-1}$. We maintained the same experimental parameters throughout the experiment to avoid their effect. For the collection of conventional SERS spectra, a long pass filter (HHQ495LP) was positioned in front of the entrance slit of a monochromator (Triax 550, Jobin Yvon). The Raman spectra were collected by a LN2-CCD (Princeton Instruments) which was cooled at about $-100{ }^{\circ} \mathrm{C}$.

2.4. DFT Calculations. The geometry optimization and Raman frequency calculations of the signaling compounds and cAMP were performed using the DFT method on B3LYP/6$31 \mathrm{G}(\mathrm{d})$ and B3PW91/LANL2DZ levels and Gaussian 09 package. The obtained frequencies from B3LYP/6-31G(d) level calculations were scaled by a factor of $0.9614,{ }^{105}$ whereas the frequencies obtained from B3PW91/LANL2DZ levels were used without applying any scaling factor (Figure S3). The DFT Raman spectra of the signaling compounds are provided in Figure S4. All calculations were carried out on a vector processor (Ohio Supercomputer Center, Columbus, Ohio).

\section{RESULTS AND DISCUSSION}

Raman spectroscopic probing of interactions between signaling compounds and DARs relies on effective experimental procedures including successful internalization of AgNP@ 
$\mathrm{SiO}_{2}$ and probing of intracellular cAMP in living cells. We discuss the important experimental procedure under the following subtopics.

3.1. Internalization of Metal NPs $\left(\mathrm{AgNP} @ \mathrm{SiO}_{2}\right)$. We studied the interaction of signaling compounds with D1 and D2 DARs using the combined approach of the SERS measurement, optical microscopy, and DFT calculations. We added finely dispersed $\mathrm{AgNP} @ \mathrm{SiO}_{2}$ on cells, which passes through the semipermeable membrane to the cytoplasm. For the fine dispersion of NPs, the AgNP@SiO 2 colloids were vortexed for $15 \mathrm{~min}$ before addition to cell samples. The differential interference contrast (DIC) imaging analysis was utilized to test the internalization of AgNP@SiO ${ }_{2}$ in the cells (Figure 2). We assumed that the internalized NP is in the same

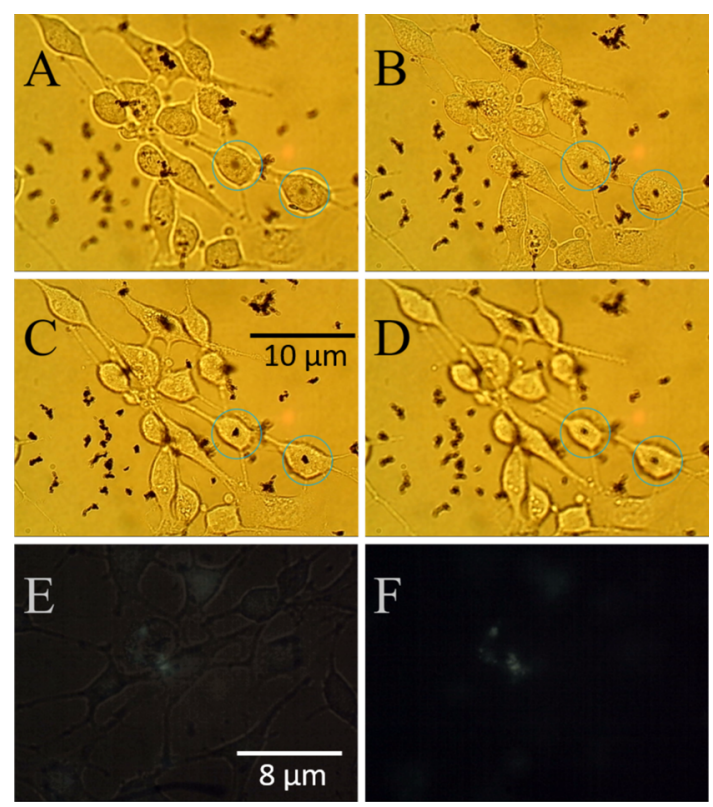

Figure 2. DIC image of DRD1-overexpressed HEK293 cells in DA solution of $0.2 \mu \mathrm{M}$ concentration. The internalized $\mathrm{AgNP}_{2} \mathrm{SiO}_{2}$ in cells is confirmed by changing the focusing modes of the microscope: (A) up-focus, (B) focus, (C) down-focus, and (D) further down-focus conditions. On the basis of the DIC image, we assumed that internalized NPs are in the same plane as outsider NPs on a cover glass. The Raman image related to cAMP $\left(780 \mathrm{~cm}^{-1}\right)$ due to interaction of DRD1 with DA is collected using a $488 \mathrm{~nm}$ CW excitation laser of $10-15 \mu \mathrm{W}$ power and a band-pass filter of $508.5 \pm$ $2 \mathrm{~nm}$ by a CMOS industrial charge-coupled device (CCD) camera (RS-500C). The image in (E) is obtained using weak white light and a CW laser, whereas the image in $(\mathrm{F})$ is obtained using a CW laser only.

plane as the outsider NPs on a cover glass. The outsider NPs on the top of the cell membrane were observed clearly at the up-focusing mode of the objective lens (Figure 2A). In this mode, both outsider NPs on the cover glass and internalized NPs were feeble. However, both outsider NPs on the cover glass and internalized NPs were darker when the objective of microscope was in the down-focusing mode (Figure 2C). Our NPs took longer time $(\sim 18 \mathrm{~h})$ for internalization in cells because these NPs were not specifically modified to target the cytoplasm. This incubation time could be decreased significantly by tethering cytoplasm-targeting ligands on the NPs. ${ }^{106}$ We observed few events of cluster formation of welldispersed NPs after internalization, which is important for the enhancement of Raman intensity.
3.2. Probing of Intracellular CAMP in HEK293 Cells. After internalization of $\mathrm{AgNP} @ \mathrm{SiO}_{2}$ in four types of cells: baseline HEK293 cells, DRD1-expressed HEK293 cells, DRD2-expressed HEK293 cells, and DRD1-DRD2-coexpressed HEK293 cells, the SERS spectra from these cells were collected under two different conditions. Condition 1 corresponds to the presence of signaling compounds such as DA, AMP, MAMP, and MDPV, and condition 2 corresponds to the absence of signaling compounds. For condition 1, the signaling compound was added $2 \mathrm{~h}$ after the addition of AgNP@SiO ${ }_{2}$. We found that when DRD1-overexpressed cells interacted with a signaling compound, the intracellular level of the cAMP level was induced, which was confirmed by the observation of cAMP-related signature peaks at 780 and 1503 $\mathrm{cm}^{-1}$. We used five Petri dishes of DA-DRD1 cells to test the cAMP-related SERS peaks and found that 4-5 cells out of 20 randomly selected cells from a Petri dish showed cAMP-related SERS peaks, and out of 100 cells from five Petri dishes, 22\% cells showed cAMP-related peaks. In similar experiments in 100 DA-DRD2 cells, $0 \%$ cells showed cAMP-related peaks. In addition, we also collected the mode-selective SERS image of $780 \mathrm{~cm}^{-1}$ using a $508.5 \pm 2 \mathrm{~nm}$ band-pass filter and a CMOS industrial CCD camera (RS-500C). In this experiment, out of 20 randomly selected DA-DRD1 cells from a Petri dish, 5-8 cells showed the Raman image related to $780 \mathrm{~cm}^{-1}$, and out of 100 DA-DRD1 cells from five Petri dishes, 37\% cells showed the Raman image related to $780 \mathrm{~cm}^{-1}$. For similar experiments in 100 DA-DRD2 cells, 7\% of them showed the Raman image related to $780 \mathrm{~cm}^{-1}$. Minor discrepancies are found between the occurrence of Raman peaks and the Raman image, which is due to the wide range of the band-pass filter. The spectral range of the band-pass filter $(508.5 \pm 2 \mathrm{~nm})$ is particularly higher to collect the mode-selective Raman image related to $780 \mathrm{~cm}^{-1}$, that is why the mode-selective Raman image could be contributed by other Raman wavenumbers too. Similarly, $2 \%$ cells out of 100 DRD1-DRD2-coexpressed cells showed the cAMP-related SERS peaks, whereas $9 \%$ of them showed the mode-selective Raman image related to $780 \mathrm{~cm}^{-1}$. The statistics of cAMP-related peaks and images are summarized in Figure 3. The imperceptible amount of cAMP due to the interaction of DA with DRD1-DRD2-co-overexpressed cells is due to the competitive action of DRD1 and DRD2 receptors for the synthesis and depletion of cAMP, respectively. We assumed that the competitive action for the synthesis and

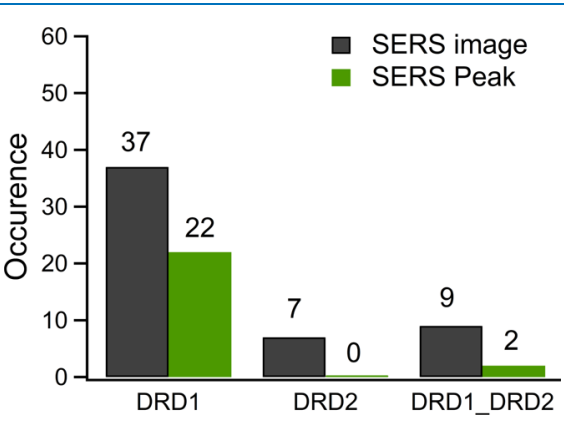

Figure 3. Percentage occurrence of cAMP-marker $\left(780 \mathrm{~cm}^{-1}\right)$ SERS peaks and SERS images observed from DA-added DRD1, DRD2, and DRD1-DRD2-expressed HEK 293 cells (out of 100 cells of each type). The spectral range of the band-pass filter $(508.5 \pm 2 \mathrm{~nm})$ is huge to collect the mode-selective Raman image, that is why \% occurrence of the mode-selective image is greater than the \% occurrence of the Raman peak. 
depletion of cAMP in cells is favored by the nonselective affinity of the four signaling compounds toward DRD1 and DRD2 receptors. Intracellular cAMP molecules formed during interactions of DRD1 with the signaling compounds are trapped by internalized AgNP@SiO 2 and probed using SERS, where the formation of cAMP was confirmed by the appearance of its signature SERS peaks at 780 and 1503 $\mathrm{cm}^{-1}$. The Raman assignment of these signature peaks of cAMP is provided elsewhere in this article.

We consider that SERS peaks at 780 and $1503 \mathrm{~cm}^{-1}$ are signatures of cAMP because these peaks were only observed in DRD1-expressed HEK293 cells in the presence of signaling compounds (Figures $4 \mathrm{~A}-\mathrm{D}$ and $5 \mathrm{~A}$ ) and pure cAMP
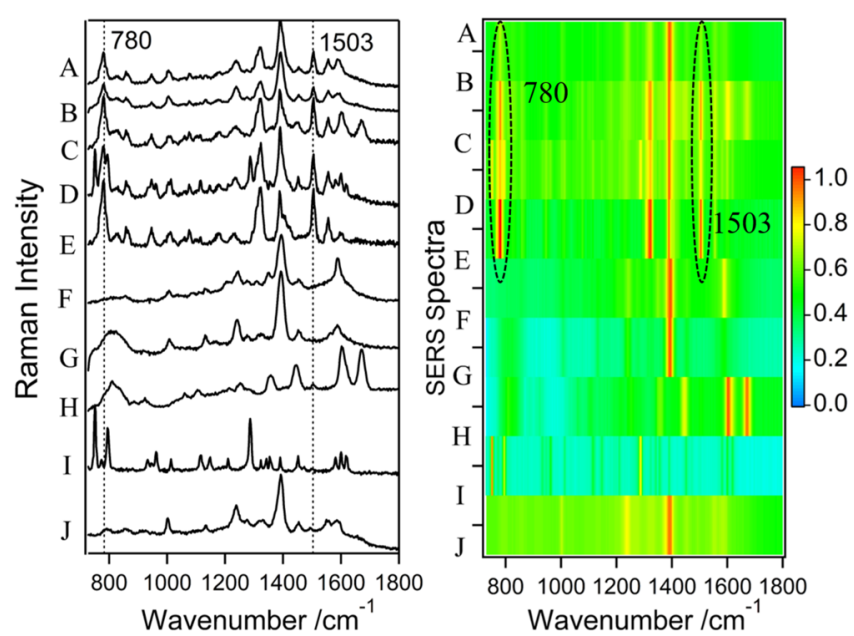

Figure 4. Integrated SERS spectra (left) and two-dimensional (2D) distribution SERS spectra (right) obtained from the DRD1-expressed HEK 293 cells in different experimental environments. The signature Raman peaks of cAMP at 780 and $1503 \mathrm{~cm}^{-1}$ are observed in the SERS spectra from DRD1-expressed cells in the presence of signaling compounds: (A) AMP, (B) MAMP, (C) MDPV, (D) DA, and (E) pure cAMP itself. These signature peaks are absent in the SERS spectrum from pure signaling compounds (just signaling compounds without any signaling compounds): (F) AMP, (G) MAMP, (H) MDPV, and (I) DA. The signature peaks are also absent in the SERS spectrum obtained from (J) DRD1-expressed HEK293 cells in the absence of the signaling compounds.

compounds (Figure 4E). Our controlled experiment showed that these SERS peaks were not observed in the pure form of all four signaling compounds (Figures 4F-I and S4) and cells (Figures 4J, S5-S8, and S9E,F). Moreover, these SERS peaks were not observed for the interaction between signaling compounds and other cells except DRD1-expressed cells (Figure 5). Our experimental results showed that the interaction between signaling molecules and DRD1 receptors induces the synthesis of cAMP in cells.

3.3. Probing of Intracellular CAMP in HT22 Cells. We extended the same experimental approach to test the interaction between DRD1 and signaling molecules in mouse hippocampal neuronal cells (HT22 cells). In this experiment, we overexpressed D1 DAR in HT22 cells by following the same procedure as explained in the Materials and Experimental Section of this article. In this experiment, we found that the interactions between DRD1-overexpressed HT22 cells and signaling molecules increase the intracellular content of cAMP. The synthesis of cAMP in HT22 cells was confirmed by observing CAMP-related signature peaks at 780 and $1503 \mathrm{~cm}^{-1}$
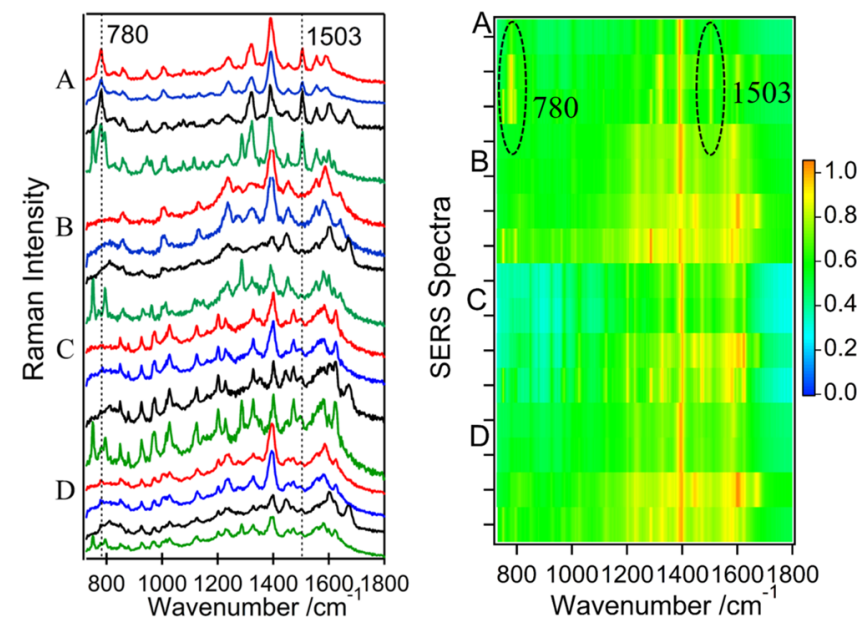

Figure 5. Integrated SERS spectra (left) and 2D distribution SERS spectra (right) obtained from (A) DRD1-expressed HEK293 cells, (B) DRD2-expressed HEK293 cells, (C) baseline HEK 293 cells, and (D) DRD1- and DRD2-coexpressed HEK293 cells in AMP (red line), MAMP (blue line), MDPV (black line), and DA (green). The Raman peaks at 780 and $1503 \mathrm{~cm}^{-1}$ are only observed in DRD1-expressed cells, which were added to the signaling compounds.

in the SERS spectra obtained from DRD1-HT22 cells in the presence of signaling compounds (Figure S9A-D). These signature peaks were not observed in DA-HT22 cells and DRD1-HT22 cells in the absence of signaling molecules (Figure S9E,F). Successful probing of intracellular cAMP in HT22 cells verifies the possibility of our experimental approach to be applied in varieties of living systems.

3.4. SERS Peak Assignment of CAMP. cAMP is an important second messenger, which is utilized as a marker in this study to probe effective interactions between DRD1 and signaling molecules such as DA, AMP, MAMP, and MDPV. We used the SERS spectra of pure cAMP to compare the SERS spectrum obtained from intracellular cAMP (Figure 4A-J). On the basis of our experimental results and DFT calculations (Figure S3), we have assigned the Raman peaks of cAMP compounds. Major SERS peaks obtained from the experimental SERS spectrum of cAMP are provided in the Supporting Information (Figure S10). Briefly, Raman peaks of cAMP in the lower-frequency region $\left(<1000 \mathrm{~cm}^{-1}\right)$ are related to $780 \mathrm{~cm}^{-1}$ : stretching of $\mathrm{C}-\mathrm{O}, \mathrm{C}-\mathrm{C}$, and $\mathrm{C}-\mathrm{N}$ bonds and symmetric and asymmetric bending of the $\mathrm{O}-\mathrm{H}$ bond; $824 \mathrm{~cm}^{-1}$ : normal mode and bending of rings (III) and (IV); $858 \mathrm{~cm}^{-1}: \mathrm{C}_{1}-\mathrm{H}_{28}$ bending and ring (III) and (IV) breathing modes; $946 \mathrm{~cm}^{-1}$ : symmetric stretching and asymmetric bending of $\mathrm{PO}_{3}{ }^{2-}$, stretching of $\mathrm{O}_{10}-\mathrm{H}_{13}, \mathrm{C}_{8}-$ $\mathrm{C}_{19}$, and $\mathrm{C}_{19}-\mathrm{C}_{18}$ bonds, and $\mathrm{C}-\mathrm{H}$ twisting in ring (I). Raman peaks of cAMP in the higher-frequency region $\left(>1000 \mathrm{~cm}^{-1}\right)$ are related to $1013 \mathrm{~cm}^{-1}$ : normal mode, $\mathrm{NH}_{2}$ rocking, and symmetric stretching of $\mathrm{PO}_{3}{ }^{2-} ; 1060 \mathrm{~cm}^{-1}$ : ring (II) and (III) stretching and $\mathrm{NH}_{2}$ rocking; $1076 \mathrm{~cm}^{-1}: \mathrm{C}_{12}-\mathrm{O}_{9}$ stretching and $\mathrm{CH}_{2}$ rocking; 1096 and $1115 \mathrm{~cm}^{-1}$ : ring stretching; 1145 $\mathrm{cm}^{-1}$ : C-C stretching and $\mathrm{CH}_{2}$ rocking; $1177 \mathrm{~cm}^{-1}$ : C-C stretching, $\mathrm{O}_{9}-\mathrm{H}_{3}$ bending, and ring (II), (III), and (IV) breathing modes; $1228 \mathrm{~cm}^{-1}: \mathrm{H}_{28}-\mathrm{C}_{1}-\mathrm{H}_{21}$ bending and $\mathrm{NH}_{2}$ rocking; $1270 \mathrm{~cm}^{-1}$ : $\mathrm{C}-\mathrm{H}$ bending and $\mathrm{C}-\mathrm{N}$ stretching; 1323 $\mathrm{cm}^{-1}$ and $1388 \mathrm{~cm}^{-1}$ : $\mathrm{C}-\mathrm{H}$ bending, $\mathrm{C}=\mathrm{N}$ stretching, and $\mathrm{C}-\mathrm{N}$ stretching; $1407 \mathrm{~cm}^{-1}$ : ring (III) and (IV) stretching and $\mathrm{C}-\mathrm{H}$ bending; $1503 \mathrm{~cm}^{-1}: \mathrm{O}_{9}-\mathrm{H}_{3}$ bending; $1556 \mathrm{~cm}^{-1}: \mathrm{CH}_{2}$ scissoring, ring (III) and (IV) stretching, and $\mathrm{NH}_{2}$ scissoring; 
$1602 \mathrm{~cm}^{-1}$ : ring (III) and (IV) deformation and $\mathrm{N}-\mathrm{H}$ bending. The assignment of experimental SERS peaks obtained from the pure cAMP compound is summarized in Table TS1.

3.5. SERS Peak Assignment of DRD1-HEK293 Cells. DARs can be controlled genetically in cells by overexpression, knockdown, or knockout approaches. In our experiment, the overexpression of DRD1 and DRD2 was easily tested and confirmed by fluorescence microscopy because they were genetically tagged with tango and green fluorescence proteins, respectively. The SERS spectra of HEK293 cells and HT22 cells were changed after overexpression of DARs. The assignment of all SERS peaks of cells is difficult. Therefore, here we have just assigned the prominent SERS peaks of DRD1-overexpressed HEK293 cells (Figure S11). SERS peaks of DRD1-expressed HEK293 cells in the low-frequency region $\left(<1000 \mathrm{~cm}^{-1}\right)$ are related to $790 \mathrm{~cm}^{-1}: \omega(\mathrm{C} \delta-\mathrm{H})$ (his); 863 $\mathrm{cm}^{-1}: \omega(\mathrm{C} \delta-\mathrm{H})$ of hist and $\tau(\mathrm{C} \varsigma-\mathrm{N} \eta 2)$ of $\mathrm{Arg} ; 916 \mathrm{~cm}^{-1}$ : $\mathrm{C}-\mathrm{C}$ stretch, $\mathrm{C} \delta$ wag, and $\mathrm{C} \alpha-\mathrm{C} \beta$ of Lys and $\nu(\mathrm{C}-\mathrm{C})$ of phe. The SERS peaks in the higher-frequency region $(>1000)$ are related to $1002 \mathrm{~cm}^{-1}$ : ring deformation of Phe; $1136 \mathrm{~cm}^{-1}$ : $\mathrm{NH}_{3}{ }^{+}$asymmetric rocking and ${ }^{-} \mathrm{OOC}-\mathrm{C} \alpha-\mathrm{H} \alpha$ of Lys; 1241 $\mathrm{cm}^{-1}$ : $\mathrm{CH}_{2}$ twisting of Met; $1275 \mathrm{~cm}^{-1}: \mathrm{N} \delta-\mathrm{C} \delta-\mathrm{H} ; \mathrm{N} \gamma-$ $\mathrm{C} \delta-\mathrm{H}$ of His; $1330 \mathrm{~cm}^{-1}: \mathrm{CH}_{2}$ wag of Met; $1392 \mathrm{~cm}^{-1}$ : $\mathrm{NH}_{3}{ }^{+}-\mathrm{C}-\mathrm{H}$ and $\mathrm{C} \beta-\mathrm{C} \alpha-\mathrm{H} \alpha$ of Ile; $1454 \mathrm{~cm}^{-1}: \mathrm{H} \alpha-\mathrm{C} \alpha-$ $\mathrm{H}, \mathrm{N}-\mathrm{C} \alpha-\mathrm{H} \alpha$, and $\mathrm{CH}_{3}$ asymmetric deformation mode of Met; $1492 \mathrm{~cm}^{-1}: \mathrm{N} \delta-\mathrm{C} \delta$ and $\mathrm{N} \delta-\mathrm{C} \delta-\mathrm{H}$ of His; $1554 \mathrm{~cm}^{-1}$ : amide II bands; and $1587 \mathrm{~cm}^{-1}$ : ${ }^{-}$OOC asymmetric stretch of Ala, $\mathrm{C} \gamma-\mathrm{C} \delta, \mathrm{C} \beta-\mathrm{C} \gamma$, and $\mathrm{N} \delta-\mathrm{C} \gamma-\mathrm{C} \delta$ stretch of His. These SERS peak assignments of DRD1-HEK293 cells are based on our experimental results and literature values related to the Raman frequency of the amino acid residue, which are summarized in Table TS2. ${ }^{107-116}$

3.6. Characterization of Signaling Compounds. This study is successful to characterize the affinity of signaling compounds toward DRD1 and DRD2. Four signaling compounds: AMP, MAMP, MDPV, and DA induced the intracellular cAMP when they had interactions with DRD1 (Figure 5A). However, these signaling compounds failed to induce intracellular cAMP when they had interactions with DRD1-DRD2-co-overexpressed cells (Figure 5D). It is a wellestablished fact that the synthesis of intracellular cAMP is induced by the interaction between DRD1 and its agonist and depleted by the interaction between DRD2 and its agonist. On the basis of this fact, we conclude that AMP, MAMP, MDPV, and DA are the agonists for both DRD1 and DRD2 and they have equal affinity toward DRD1 and DRD2.

\section{CONCLUSIONS}

When signaling compounds such as DA, AMP, MAMP, or MDPV interact effectively with D1 DARs, the level of cAMP is induced in cells. We internalized silica-coated AgNPs (AgNP@ $\left.\mathrm{SiO}_{2}\right)$ in cells, which adsorbed the biologically synthesized cAMP molecules and served as a SERS substrate to enhance the Raman cross section of cAMP. Our experimental approach collected SERS spectra from intracellular cAMP using lowpower laser excitation with a short exposure time, which is very useful for in vivo studies. Our experimental results and DFT calculations showed that 780 and $1503 \mathrm{~cm}^{-1}$ are the signature Raman wavenumbers of cAMP. The SERS peak of cAMP at $780 \mathrm{~cm}^{-1}$ is associated with $\mathrm{C}-\mathrm{O}, \mathrm{C}-\mathrm{C}$, and $\mathrm{C}-\mathrm{N}$ stretching and symmetric and asymmetric bending of two $\mathrm{O}-\mathrm{H}$ bonds, whereas the SERS peak at $1503 \mathrm{~cm}^{-1}$ is found to be contributed by the $\mathrm{O}_{9}-\mathrm{H}_{3}$ bending mode. On the basis of the intracellular level of induced cAMP, we characterized the effective interaction between DRD1 and its agonist and distinguished the affinity of signaling compounds toward specific types of DARs. In this work, signaling compounds such as AMP, MAMP, MDPV, and DA showed equal affinity toward both DRD1 and DRD2 DARs. In summary, our experimental approach is successful to probe the overexpression of D1 and D2 DARs, measure the intracellular level of cAMP, and characterize the affinity of signaling compounds toward a specific DAR.

\section{ASSOCIATED CONTENT}

\section{Supporting Information}

The Supporting Information is available free of charge on the ACS Publications website at DOI: 10.1021/acsomega.8b01727.

SERS imaging condition, Raman microscopic instrumentation, computationally calculated Raman spectra, and Raman spectra of control experiments (PDF)

\section{AUTHOR INFORMATION}

\section{Corresponding Author}

*E-mail: hplu@bgsu.edu.

ORCID

H. Peter Lu: 0000-0003-2027-428X

Notes

The authors declare no competing financial interest.

\section{ACKNOWLEDGMENTS}

We acknowledge the support from the Ohio Eminent Scholar endowment fund and the Ohio Attorney General's Center for the Future of Forensic Science Research Fund, Ohio.

\section{ABBREVIATIONS}

cAMP, cyclic adenosine monophosphate; DA, dopamine; HEK cells, human embryonic kidney cells; HT22, mouse hippocampal neuronal cell; hDAT, human dopamine transporter; DAR, dopamine receptor; SERS, surface-enhanced Raman spectroscopy; DRD1, D1 dopamine receptor; DRD2, D2 dopamine receptor

\section{REFERENCES}

(1) Fredriksson, R.; Lagerström, M. C.; Lundin, L.-G.; Schiöth, H. B. The G-protein-coupled receptors in the human genome form five main families. Phylogenetic analysis, paralogon groups, and fingerprints. Mol. Pharmacol. 2003, 63, 1256-1272.

(2) Kristiansen, K. Molecular mechanisms of ligand binding, signaling, and regulation within the superfamily of G-protein-coupled receptors: molecular modeling and mutagenesis approaches to receptor structure and function. Pharmacol. Ther. 2004, 103, 21-80.

(3) Polymeropoulos, M. H.; Xiao, H.; Merril, C. R. The human D5 dopamine receptor (DRD5) maps on chromosome 4. Genomics 1991, 11, 777-778.

(4) Dearry, A.; Gingrich, J. A.; Falardeau, P.; Fremeau, R. T., Jr.; Bates, M. D.; Caron, M. G. Molecular cloning and expression of the gene for a human D1 dopamine receptor. Nature 1990, 347, 72-76.

(5) Zhou, Q.-Y.; Grandy, D. K.; Thambi, L.; Kushner, J. A.; Van Tol, H. H. M.; Cone, R.; Pribnow, D.; Salon, J.; Bunzow, J. R.; Civelli, O. Cloning and expression of human and rat Dt dopamine receptors. Nature 1990, 347, 76-80.

(6) Sunahara, R. K.; Niznik, H. B.; Weiner, D. M.; Stormann, T. M.; Brann, M. R.; Kennedy, J. L.; Gelernter, J. E.; Rozmahel, R.; Yang, Y.; Israel, Y.; Seeman, P.; O’Dowd, B. F. Human dopamine D1 receptor 
encoded by an intronless gene on chromosome 5. Nature 1990, 347, $80-83$.

(7) Conroy, J. L.; Free, R. B.; Sibley, D. R. Identification of G protein-biased agonists that fail to recruit $\beta$-arrestin or promote internalization of the D1 dopamine receptor. ACS Chem. Neurosci. 2015, 6, 681-692.

(8) Kim, K.-M.; Valenzano, K. J.; Robinson, S. R.; Yao, W. D.; Barak, L. S.; Caron, M. G. Differential regulation of the dopamine D2 and $\mathrm{D} 3$ receptors by $\mathrm{G}$ protein-coupled receptor kinases and $\beta$-arrestins. J. Biol. Chem. 2001, 276, 37409-37414.

(9) DeWire, S. M.; Ahn, S.; Lefkowitz, R. J.; Shenoy, S. K. $\beta$-arrestins and cell signaling. Annu. Rev. Physiol. 2007, 69, 483-510.

(10) Lee, H.-K.; Takamiya, K.; Han, J.-S.; Man, H.; Kim, C.-H.; Rumbaugh, G.; Yu, S.; Ding, L.; He, C.; Petralia, R. S.; Wenthold, R. J.; Gallagher, M.; Huganir, R. L. Phosphorylation of the AMPA receptor GluR1 subunit is required for synaptic plasticity and retention of spatial memory. Cell 2003, 112, 631-643.

(11) Liu, F.; Wan, Q.; Pristupa, Z. B.; Yu, X.-M.; Wang, Y. T.; Niznik, H. B. Direct protein-protein coupling enables cross-talk between dopamine D5 and $\gamma$-aminobutyric acid A receptors. Nature 2000, 403, 274-280.

(12) Tritsch, N. X.; Sabatini, B. L. Dopaminergic modulation of synaptic transmission in cortex and striatum. Neuron 2012, 76, 3350.

(13) Beaulieu, J.-M.; Gainetdinov, R. R. The physiology, signaling, and pharmacology of dopamine receptors. Pharmacol. Rev. 2011, 63, 182-217.

(14) Usiello, A.; Baik, J.-H.; Rougé-Pont, F.; Picetti, R.; Dierich, A.; LeMeur, M.; Piazza, P. V.; Borrelli, E. Distinct functions of the two isoforms of dopamine D2 receptors. Nature 2000, 408, 199-203.

(15) Greengard, P.; Allen, P. B.; Nairn, A. C. Beyond the dopamine receptor. Neuron 1999, 23, 435-447.

(16) Surmeier, D. J.; Eberwine, J.; Wilson, C. J.; Cao, Y.; Stefani, A.; Kitai, S. T. Dopamine receptor subtypes colocalize in rat striatonigral neurons. Proc. Natl. Acad. Sci. U. S. A. 1992, 89, 10178-10182.

(17) Surmeier, D. J.; Bargas, J.; Hemmings, H. C., Jr.; Nairn, A. C.; Greengard, P. Modulation of calcium currents by a D1 dopaminergic protein kinase/phosphatase cascade in rat neostriatal neurons. Neuron 1995, 14, 385-397.

(18) Cepeda, C.; Chandler, S. H.; Shumate, L. W.; Levine, M. S. Persistent $\mathrm{Na}^{+}$conductance in medium-sized neostriatal neurons: characterization using infrared videomicroscopy and whole cell patchclamp recordings. J. Neurophysiol. 1995, 74, 1343-1348.

(19) Hernández-López, S.; Bargas, J.; Surmeier, D. J.; Reyes, A.; Galarraga, E. D1 receptor activation enhances evoked discharge in neostriatal medium spiny neurons by modulating an L-type $\mathrm{Ca}^{+}$ conductance. J. Neurosci. 1997, 17, 3334-3342.

(20) Andersson, M.; Konradi, C.; Cenci, M. A. cAMP response element-binding protein is required for dopamine-dependent gene expression in the intact but not the dopamine-denervated striatum. J. Neurosci. 2001, 21, 9930-9943.

(21) Pillai, G.; Brown, N. A.; McAllister, G.; Milligan, G.; Seabrook, G. R. Human D2 and D4 dopamine receptors couple through $\beta \gamma$ Gprotein subunits to inwardly rectifying $\mathrm{K}^{+}$channels (GIRK1) in a Xenopus oocyte expression system: selective antagonism by L741,626 and L-745,870 respectively. Neuropharmacology 1998, 37, 983-987.

(22) Kuzhikandathil, E. V.; Yu, W.; Oxford, G. S. Human dopamine D3 and D2L receptors couple to inward rectifier potassium channels in mammalian cell lines. Mol. Cell. Neurosci. 1998, 12, 390-402.

(23) Rahman, N.; Buck, J.; Levin, L. R. pH sensing via bicarbonateregulated "soluble" adenylyl cyclase (sAC). Front. Physiol. 2013, 4, 343.

(24) Rahman, N.; Ramos-Espiritu, L.; Milner, T. A.; Buck, J.; Levin, L. R. Soluble adenylyl cyclase is essential for proper lysosomal acidification. J. Gen. Physiol. 2016, 148, 325-339.

(25) Levin, L. R.; Buck, J. Physiological roles of acid-base sensors. Annu. Rev. Physiol. 2015, 77, 347-362.
(26) Castellucci, V. F.; Kandel, E. R.; Schwartz, J. H.; Wilson, F. D.; Nairn, A. C.; Greengard, P. Intracellular injection of the catalytic subunit of cyclic AMP-dependent protein kinase simulates facilitation of transmitter release underlying behavioral sensitization in Aplysia. Proc. Natl. Acad. Sci. U. S. A. 1980, 77, 7492-7496.

(27) Ali, E. S.; Hua, J.; Wilson, C. H.; Tallis, G. A.; Zhou, F. H.; Rychkov, G. Y.; Barritt, G. J. The glucagon-like peptide-1 analogue exendin-4 reverses impaired intracellular $\mathrm{Ca}^{2+}$ signalling in steatotic hepatocytes. Biochim. Biophys. Acta, Mol. Cell Res. 2016, 1863, 21352146.

(28) Frohman, L. A.; Kineman, R. D.; Kamegai, J.; Park, S.; Teixeira, L. T.; Coschigano, K. T.; Kopchic, J. Secretagogues and the somatotrope: signaling and proliferation. Recent Prog. Horm. Res. 2000, 55, 269-290.

(29) Frohman, L. A.; Kineman, R. D. Growth hormone-releasing hormone and pituitary development, hyperplasia and tumorigenesis. Trends Endocrinol. Metab. 2002, 13, 299-303.

(30) Maheshwari, H. G.; Rahim, A.; Shalet, S. M.; Baumann, G. Selective lack of growth hormone $(\mathrm{GH})$ response to the GH-releasing peptide hexarelin in patients with GH-releasing hormone receptor deficiency. J. Clin. Endocrinol. Metab. 1999, 84, 956-959.

(31) Luckey, J. A.; Drossman, H.; Kostichka, T.; Smith, L. M. [12] High-speed DNA sequencing by capillary gel electrophoresis. Methods in Enzymology; Elsevier, 1993; Vol. 218, pp 154-172.

(32) Ninfa, A. J.; Ballou, D. P.; Parsons, M. B. P. Fundamental Laboratory Approaches for Biochemistry and Biotechnology; Wiley, 1998; pp 247-271

(33) Mullis, K. B.; Faloona, F. A. Specific synthesis of DNA in vitro via a polymerase-catalyzed chain reaction. Recombinant DNA Methodology; Elsevier, 1989; pp 189-204.

(34) Sittampalam, G. S.; Kahl, S. D.; Janzen, W. P. High-throughput screening: advances in assay technologies. Curr. Opin. Chem. Biol. 1997, 1, 384-391.

(35) de Jong, L. A. A.; Uges, D. R. A.; Franke, J. P.; Bischoff, R. Receptor-ligand binding assays: technologies and applications. $J$. Chromatogr. B: Anal. Technol. Biomed. Life Sci. 2005, 829, 1-25.

(36) Lakowicz, J. R. Topics in Fluorescence Spectroscopy: Volume 4: Probe Design and Chemical Sensing; Springer Science \& Business Media, 1994; Vol. 4.

(37) Bailey, D. L.; Townsend, D. W.; Valk, P. E.; Maisey, M. N. Positron Emission Tomography; Springer, 2005.

(38) Jaszczak, R. J.; Greer, K. L.; Floyd, J. C.; Harris, C. C.; Coleman, R. E. Improved SPECT quantification using compensation for scattered photons. J. Nucl. Med. 1984, 25, 893-900.

(39) Inglese, J.; Auld, D. S.; Jadhav, A.; Johnson, R. L.; Simeonov, A.; Yasgar, A.; Zheng, W.; Austin, C. P. Quantitative high-throughput screening: a titration-based approach that efficiently identifies biological activities in large chemical libraries. Proc. Natl. Acad. Sci. U. S. A. 2006, 103, 11473-11478.

(40) Chudakov, D. M.; Verkhusha, V. V.; Staroverov, D. B.; Souslova, E. A.; Lukyanov, S.; Lukyanov, K. A. Photoswitchable cyan fluorescent protein for protein tracking. Nat. Biotechnol. 2004, 22, $1435-1439$

(41) Sorkina, T.; Doolen, S.; Galperin, E.; Zahniser, N. R.; Sorkin, A. Oligomerization of dopamine transporters visualized in living cells by fluorescence resonance energy transfer microscopy. J. Biol. Chem. 2003, 278, 28274-28283.

(42) Furman, C. A.; Chen, R.; Guptaroy, B.; Zhang, M.; Holz, R. W.; Gnegy, M. Dopamine and amphetamine rapidly increase dopamine transporter trafficking to the surface: live-cell imaging using total internal reflection fluorescence microscopy. J. Neurosci. 2009, 29, $3328-3336$

(43) Kung, H. F.; Kim, H.-J.; Kung, M.-P.; Meegalla, S. K.; Plössl, K.; Lee, H.-K. Imaging of dopamine transporters in humans with technetium-99m TRODAT 1. Eur. J. Nucl. Med. 1996, 23, 15271530.

(44) Laruelle, M.; Baldwin, R. M.; Malison, R. T.; Zea-Ponce, Y.; Zoghbi, S. S.; Al-Tikeriti, M. S.; Sybirska, E. H.; Zimmermann, R. C.; Wisniewski, G.; Neumeyer, J. L.; Milius, R. A.; Wang, S.; Smith, E. O.; 
Roth, R. H.; Charney, D. S.; Hoffer, P. B.; Innis, R. B. SPECT imaging of dopamine and serotonin transporters with [123I] $\beta$-CIT: Pharmacological characterization of brain uptake in nonhuman primates. Synapse 1993, 13, 295-309.

(45) Malison, R. T.; Price, L. H.; Berman, R.; van Dyck, C. H.; Pelton, G. H.; Carpenter, L.; Sanacora, G.; Owens, M. J.; Nemeroff, C. B.; Rajeevan, N.; Baldwin, R. M.; Seibyl, J. P.; Innis, R. B.; Charney, D. S. Reduced brain serotonin transporter availability in major depression as measured by $[123 \mathrm{I}]-2 \hat{\mathrm{I}}^{2}$-carbomethoxy-3$\hat{\mathrm{I}}^{2}-(4-$ iodophenyl) tropane and single photon emission computed tomography. Biol. Psychiatry 1998, 44, 1090-1098.

(46) Booij, J.; Tissingh, G.; Boer, G. J.; Speelman, J. D.; Stoof, J. C.; Janssen, A. G.; Wolters, E. C.; van Royen, E. A. [123I] FP-CIT SPECT shows a pronounced decline of striatal dopamine transporter labelling in early and advanced Parkinson's disease. J. Neurol., Neurosurg. Psychiatry 1997, 62, 133-140.

(47) Kantcheva, A. K.; Quick, M.; Shi, L.; Winther, A.-M. L.; Stolzenberg, S.; Weinstein, H.; Javitch, J. A.; Nissen, P. Chloride binding site of neurotransmitter sodium symporters. Proc. Natl. Acad. Sci. U. S. A. 2013, 110, 8489-8494.

(48) Khafizov, K.; Perez, C.; Koshy, C.; Quick, M.; Fendler, K.; Ziegler, C.; Forrest, L. R. Investigation of the sodium-binding sites in the sodium-coupled betaine transporter BetP. Proc. Natl. Acad. Sci. U. S. A. 2012, 109, E3035-E3044.

(49) Shaikh, S. A.; Tajkhorshid, E. Modeling and dynamics of the inward-facing state of a $\mathrm{Na}^{+} / \mathrm{Cl}^{-}$dependent neurotransmitter transporter homologue. PLoS Comput. Biol. 2010, 6, e1000905.

(50) Zomot, E.; Bahar, I. A conformational switch in a partially unwound helix selectively determines the pathway for substrate release from the carnitine $/ \gamma$-butyrobetaine antiporter CaiT. J. Biol. Chem. 2012, 287, 31823-31832.

(51) Thomas, J. R.; Gedeon, P. C.; Grant, B. J.; Madura, J. D. LeuT conformational sampling utilizing accelerated molecular dynamics and principal component analysis. Biophys. J. 2012, 103, L1-L3.

(52) Stockner, T.; Montgomery, T. R.; Kudlacek, O.; Weissensteiner, R.; Ecker, G. F.; Freissmuth, M.; Sitte, H. H. Mutational analysis of the high-affinity zinc binding site validates a refined human dopamine transporter homology model. PLoS Comput. Biol. 2013, 9, e1002909.

(53) Hamelberg, D.; Mongan, J.; McCammon, J. A. Accelerated molecular dynamics: a promising and efficient simulation method for biomolecules. J. Chem. Phys. 2004, 120, 11919-11929.

(54) Miao, Y.; Nichols, S. E.; Gasper, P. M.; Metzger, V. T.; McCammon, J. A. Activation and dynamic network of the M2 muscarinic receptor. Proc. Natl. Acad. Sci. U. S. A. 2013, 110, 1098210987.

(55) Penmatsa, A.; Wang, K. H.; Gouaux, E. X-ray structure of dopamine transporter elucidates antidepressant mechanism. Nature 2013, 503, 85-90.

(56) Wang, K. H.; Penmatsa, A.; Gouaux, E. Neurotransmitter and psychostimulant recognition by the dopamine transporter. Nature 2015, 521, 322-327.

(57) Paul, B. K.; Ghosh, N.; Mukherjee, S. Interaction of an anticancer photosensitizer with a genomic DNA: From base pair specificity and thermodynamic landscape to tuning the rate of detergent-sequestered dissociation. J. Colloid Interface Sci. 2016, 470, 211-220.

(58) Jaiswal, N.; Saraswat, S.; Ratnam, M.; Isailovic, D. Analysis of folate binding protein $\mathrm{N}$-linked glycans by mass spectrometry. $J$. Proteome Res. 2012, 11, 1551-1560.

(59) Cameron, K. N.; Kolanos, R.; Solis, E.; Glennon, R. A.; De Felice, L. J. Bath salts components mephedrone and methylenedioxypyrovalerone (MDPV) act synergistically at the human dopamine transporter. Br. J. Pharmacol. 2013, 168, 1750-1757.

(60) Axelrod, D.; Koppel, D. E.; Schlessinger, J.; Elson, E.; Webb, W. $\mathrm{W}$. Mobility measurement by analysis of fluorescence photobleaching recovery kinetics. Biophys. J. 1976, 16, 1055-1069.

(61) Nadeau, V.; O’Dwyer, M.; Hamdan, K.; Tait, I.; Padgett, M. In vivo measurement of 5-aminolaevulinic acid-induced protoporphyrin
IX photobleaching: a comparison of red and blue light of various intensities. Photodermatol., Photoimmunol. Photomed. 2004, 20, 170174.

(62) Kong, X.; Nir, E.; Hamadani, K.; Weiss, S. Photobleaching pathways in single-molecule FRET experiments. J. Am. Chem. Soc. 2007, 129, 4643-4654.

(63) Benson, D. M.; Bryan, J.; Plant, A. L.; Gotto, A. M.; Smith, L. C. Digital imaging fluorescence microscopy: spatial heterogeneity of photobleaching rate constants in individual cells. J. Cell Biol. 1985, 100, 1309-1323.

(64) Hoebe, R. A.; Van Oven, C. H.; Gadella, T. W. J.; Dhonukshe, P. B.; Van Noorden, C. J. F.; Manders, E. M. M. Controlled lightexposure microscopy reduces photobleaching and phototoxicity in fluorescence live-cell imaging. Nat. Biotechnol. 2007, 25, 249-253.

(65) Aveline, B. M.; Sattler, R. M.; Redmond, R. W. Environmental effects on cellular photosensitization: correlation of phototoxicity mechanism with transient absorption spectroscopy measurements. Photochem. Photobiol. 1998, 68, 51-62.

(66) Purschke, M.; Rubio, N.; Held, K. D.; Redmond, R. W. Phototoxicity of Hoechst 33342 in time-lapse fluorescence microscopy. Photochem. Photobiol. Sci. 2010, 9, 1634-1639.

(67) Ding, F.; Lee, K. J.; Vahedi-Faridi, A.; Yoneyama, H.; Osgood, C. J.; Xu, X.-H. N. Design and study of the efflux function of the EGFP fused MexAB-OprM membrane transporter in Pseudomonas aeruginosa using fluorescence spectroscopy. Analyst 2014, 139, $3088-3096$.

(68) Ding, F.; Lee, K. J.; Vahedi-Faridi, A.; Huang, T.; Xu, X.-H. N. Design and probing of efflux functions of EGFP fused $A B C$ membrane transporters in live cells using fluorescence spectroscopy. Anal. Bioanal. Chem. 2011, 400, 223-235.

(69) Davenport, A. P.; Russell, F. D. Radioligand binding assays: theory and practice. Current Directions in Radiopharmaceutical Research and Development; Springer, 1996; pp 169-179.

(70) Lewis, A.; Spoonhower, J.; Bogomolni, R. A.; Lozier, R. H.; Stoeckenius, W. Tunable laser resonance Raman spectroscopy of bacteriorhodopsin. Proc. Natl. Acad. Sci. U. S. A. 1974, 71, 44624466.

(71) Kubasek, W. L.; Wang, Y.; Thomas, G. A.; Patapoff, T. W.; Schoenwaelder, K. H.; Van der Sande, J. H.; Peticolas, W. L. Raman spectra of the model B-DNA oligomer d (CGCGAATTCGCG) 2 and of the DNA in living salmon sperm show that both have very similar B-type conformations. Biochemistry 1986, 25, 7440-7445.

(72) Puppels, G. J.; de Mul, F. F. M.; Otto, C.; Greve, J.; RobertNicoud, M.; Arndt-Jovin, D. J.; Jovin, T. M. Studying single living cells and chromosomes by confocal Raman microspectroscopy. Nature 1990, 347, 301-303.

(73) Fu, D.; Yang, W.; Xie, X. S. Label-free Imaging of Neurotransmitter Acetylcholine at Neuromuscular Junctions with Stimulated Raman Scattering. J. Am. Chem. Soc. 2017, 139, 583-586.

(74) Tao, Y.; Wang, Y.; Huang, S.; Zhu, P.; Huang, W. E.; Ling, J.; $\mathrm{Xu}, \mathrm{J}$. Metabolic-activity-based assessment of antimicrobial effects by D2O-labeled single-cell raman microspectroscopy. Anal. Chem. 2017, $89,4108-4115$.

(75) Lee, H. J.; Zhang, D.; Jiang, Y.; Wu, X.; Shih, P.-Y.; Liao, C.-S.; Bungart, B.; Xu, X.-M.; Drenan, R.; Bartlett, E.; Cheng, J.-X. LabelFree Vibrational Spectroscopic Imaging of Neuronal Membrane Potential. J. Phys. Chem. Lett. 2017, 8, 1932-1936.

(76) Cheng, J.-X.; Xie, X. S. Vibrational spectroscopic imaging of living systems: An emerging platform for biology and medicine. Science 2015, 350, aaa8870.

(77) Silwal, A. P.; Yadav, R.; Sprague, J. E.; Lu, H. P. Raman Spectroscopic Signature Markers of Dopamine-Human Dopamine Transporter Interaction in Living Cells. ACS Chem. Neurosci. 2017, 8, $1510-1518$.

(78) Cotton, T. M.; Schultz, S. G.; Van Duyne, R. P. Surfaceenhanced resonance Raman scattering from water-soluble porphyrins adsorbed on a silver electrode. J. Am. Chem. Soc. 1982, 104, 65286532 . 
(79) Cotton, T. M.; Van Duyne, R. P. Resonance Raman scattering from Rhodopseudomonas sphaeroides reaction centers absorbed on a silver electrode. FEBS Lett. 1982, 147, 81-84.

(80) Silwal, A. P.; Lu, H. P. Raman spectroscopy probing of redox states and mechanism of flavin coenzyme. J. Raman Spectrosc. 2018, $49,1311-1322$.

(81) Jeanmaire, D. L.; Van Duyne, R. P. Surface Raman spectroelectrochemistry: Part I. Heterocyclic, aromatic, and aliphatic amines adsorbed on the anodized silver electrode. J. Electroanal. Chem. Interfacial Electrochem. 1977, 84, 1-20.

(82) Lee, N. S.; Sheng, R. S.; Morris, M. D.; Schopfer, L. M. The active species in surface-enhanced Raman scattering of flavins on silver colloids. J. Am. Chem. Soc. 1986, 108, 6179-6183.

(83) Holt, R. E.; Cotton, T. M. Free flavin interference in surface enhanced resonance Raman spectroscopy of glucose oxidase. J. Am. Chem. Soc. 1987, 109, 1841-1845.

(84) Dutta, P. K.; Nestor, J. R.; Spiro, T. G. Resonance coherent anti-Stokes Raman scattering spectra of fluorescent biological chromophores: Vibrational evidence for hydrogen bonding of flavin to glucose oxidase and for rapid solvent exchange. Proc. Natl. Acad. Sci. U. S. A. 1977, 74, 4146-4149.

(85) Ma, K.; Yuen, J. M.; Shah, N. C.; Walsh, J. T., Jr.; Glucksberg, M. R.; Van Duyne, R. P. In vivo, transcutaneous glucose sensing using surface-enhanced spatially offset Raman spectroscopy: multiple rats, improved hypoglycemic accuracy, low incident power, and continuous monitoring for greater than 17 days. Anal. Chem. 2011, 83, 91469152.

(86) Henry, A.; Sharma, B.; Van Duyne, R. Continuous sensing of blood by dark-field microscopy and surface-enhanced Raman spectroscopy. Nanotechnology 2012, 3, 40-43.

(87) Campos, A. R.; Gao, Z.; Blaber, M. G.; Huang, R.; Schatz, G. C.; Van Duyne, R. P.; Haynes, C. L. Surface-Enhanced Raman Spectroscopy Detection of Ricin B Chain in Human Blood. J. Phys. Chem. C 2016, 120, 20961-20969.

(88) Pallaoro, A.; Braun, G. B.; Moskovits, M. Biotags based on surface-enhanced Raman can be as bright as fluorescence tags. Nano Lett. 2015, 15, 6745-6750.

(89) Pallaoro, A.; Hoonejani, M. R.; Braun, G. B.; Meinhart, C. D.; Moskovits, M. Rapid identification by surface-enhanced Raman spectroscopy of cancer cells at low concentrations flowing in a microfluidic channel. ACS Nano 2015, 9, 4328-4336.

(90) Qian, X.; Peng, X.-H.; Ansari, D. O.; Yin-Goen, Q.; Chen, G. Z.; Shin, D. M.; Yang, L.; Young, A. N.; Wang, M. D.; Nie, S. In vivo tumor targeting and spectroscopic detection with surface-enhanced Raman nanoparticle tags. Nat. Biotechnol. 2008, 26, 83-90.

(91) Han, J.; Qian, X.; Wu, Q.; Jha, R.; Duan, J.; Yang, Z.; Maher, K. O.; Nie, S.; Xu, C. Novel surface-enhanced Raman scattering-based assays for ultra-sensitive detection of human pluripotent stem cells. Biomaterials 2016, 105, 66-76.

(92) Takeuchi, M.; Kajimoto, S.; Nakabayashi, T. Experimental Evaluation of the Density of Water in a Cell by Raman Microscopy. J. Phys. Chem. Lett. 2017, 8, 5241-5245.

(93) Kristinaitytè, K.; Maršalka, A.; Dagys, L.; Aidas, K.; Doroshenko, I.; Vaskivskyi, Y.; Chernolevska, Y.; Pogorelov, V.; Valevičiené, N. R.; Balevicius, V. NMR, Raman, and DFT Study of Lyotropic Chromonic Liquid Crystals of Biomedical Interest: Tautomeric Equilibrium and Slow Self-Assembling in Sunset Yellow Aqueous Solutions. J. Phys. Chem. B 2018, 122, 3047-3055.

(94) Silwal, A. P.; Lu, H. P. Mode-Selective Raman Imaging of Dopamine-Human Dopamine Transporter Interaction in Live Cells. ACS Chem. Neurosci. 2018, DOI: 10.1021/acschemneuro.8b00301.

(95) De Matteis, V.; Malvindi, M. A.; Galeone, A.; Brunetti, V.; De Luca, E.; Kote, S.; Kshirsagar, P.; Sabella, S.; Bardi, G.; Pompa, P. P. Negligible particle-specific toxicity mechanism of silver nanoparticles: the role of $\mathrm{Ag}^{+}$ion release in the cytosol. Nanomedicine 2015, 11, 731-739.

(96) Kone, B. C.; Kaleta, M.; Gullans, S. R. Silver ion $\left(\mathrm{Ag}^{+}\right)$-induced increases in cell membrane $\mathrm{K}^{+}$and $\mathrm{Na}^{+}$permeability in the renal proximal tubule: reversal by thiol reagents. J. Cell Biol. 1988, 102, 1119.

(97) Staszek, M.; Siegel, J.; Rimpelová, S.; Lyutakov, O.; Švorčík, V. Cytotoxicity of noble metal nanoparticles sputtered into glycerol. Mater. Lett. 2015, 158, 351-354.

(98) Pujalté, I.; Passagne, I.; Brouillaud, B.; Tréguer, M.; Durand, E.; Ohayon-Courtès, C.; L'Azou, B. Cytotoxicity and oxidative stress induced by different metallic nanoparticles on human kidney cells. Part. Fibre Toxicol. 2011, 8, 10.

(99) Wang, Q.; Wang, Y.; Lu, H. P. Revealing the secondary structural changes of amyloid $\beta$ peptide by probing the spectral fingerprint characters. J. Raman Spectrosc. 2013, 44, 670-674.

(100) Gu, M.; Lu, H. P. Raman mode-selective spectroscopic imaging of coenzyme and enzyme redox states. J. Raman Spectrosc. 2016, 47, 801-807.

(101) Phelan, K.; May, K. M. Basic techniques in mammalian cell tissue culture. Curr. Protoc. Cell Biol. 2015, 66, 1.1.1-1.1.18.

(102) Lee, P. C.; Meisel, D. Adsorption and surface-enhanced Raman of dyes on silver and gold sols. J. Phys. Chem. 1982, 86, 33913395 .

(103) Liz-Marzán, L. M.; Giersig, M.; Mulvaney, P. Synthesis of nanosized gold-silica core-shell particles. Langmuir 1996, 12, 43294335.

(104) Lu, H. P. Site-specific Raman spectroscopy and chemical dynamics of nanoscale interstitial systems. J. Phys.: Condens. Matter 2005, 17, R333-R355.

(105) Scott, A. P.; Radom, L. Harmonic Vibrational Frequencies: An Evaluation of Hartree-Fock, Møller-Plesset, Quadratic Configuration Interaction, Density Functional Theory, and Semiempirical Scale Factors. J. Phys. Chem. C 1996, 100, 16502-16513.

(106) Kang, J. W.; So, P. T. C.; Dasari, R. R.; Lim, D.-K. High resolution live cell Raman imaging using subcellular organelletargeting SERS-sensitive gold nanoparticles with highly narrow intra-nanogap. Nano Lett. 2015, 15, 1766-1772.

(107) Zhu, G.; Zhu, X.; Fan, Q.; Wan, X. Raman spectra of amino acids and their aqueous solutions. Spectrochim. Acta, Part A 2011, 78, $1187-1195$.

(108) Lord, R. C.; Yu, N.-t. Laser-excited Raman spectroscopy of biomolecules: I. Native lysozyme and its constituent amino acids. J. Mol. Biol. 1970, 50, 509-524.

(109) Diem, M.; Polavarapu, P. L.; Oboodi, M.; Nafie, L. A. Vibrational circular dichroism in amino acids and peptides. 4. Vibrational analysis, assignments, and solution-phase Raman spectra of deuterated isotopomers of alanine. J. Am. Chem. Soc. 1982, 104, 3329-3336.

(110) Suh, J. S.; Moskovits, M. Surface-enhanced Raman spectroscopy of amino acids and nucleotide bases adsorbed on silver. J. Am. Chem. Soc. 1986, 108, 4711-4718.

(111) Stewart, S.; Fredericks, P. M. Surface-enhanced Raman spectroscopy of amino acids adsorbed on an electrochemically prepared silver surface. Spectrochim. Acta, Part A 1999, 55, 16411660.

(112) Rava, R. P.; Spiro, T. G. Resonance enhancement in the ultraviolet Raman spectra of aromatic amino acids. J. Phys. Chem. 1985, 89, 1856-1861.

(113) Podstawka, E.; Ozaki, Y.; Proniewicz, L. M. Part I: Surfaceenhanced Raman spectroscopy investigation of amino acids and their homodipeptides adsorbed on colloidal silver. Appl. Spectrosc. 2004, 58, 570-580.

(114) Asher, S. A.; Ludwig, M.; Johnson, C. R. UV resonance Raman excitation profiles of the aromatic amino acids. J. Am. Chem. Soc. 1986, 108, 3186-3197.

(115) Podstawka, E.; Ozaki, Y.; Proniewicz, L. M. Part III: Surfaceenhanced Raman scattering of amino acids and their homodipeptide monolayers deposited onto colloidal gold surface. Appl. Spectrosc. 2005, 59, 1516-1526.

(116) Edsall, J. T. Raman spectra of amino acids and related substances III. Ionization and methylation of the amino group. J. Chem. Phys. 1937, 5, 225-237. 